"Vox Patrum" 7/1987/z, $12-13$

\title{
IDEAŁ KAPŁANA WEDŁUG ŚW. EFREMA
}

Ideał kapłana od dawna był przedmiotem żywego zainteresowania. Przyczyniły się do tego w niemałej mierze dokumenty ostatniego Soboru, zwłaszcza dekrety o formacji kapłańskiej oraz o posłudze 1 życiu kapłanów. Cytuja one wiele wypowiedzi i zapożyczeń z pism ojców Kościoła, którzy na temat kapłaństwa wypowiadali się wielokrotnie. Jednym z tych, którzy kapłanistwu poświęcili niemało uwagi, był diakon Kościoła syryjskiego, jedyny doktor spoza kręgu grecko-łacińskiego - św. Efrem /+373/. Pozostawił on piękną mowę "O k a p 1 a ń $s$ t $\mathbf{~} i \mathrm{e}^{{ }^{1}}$, 1 nierzadko na jego temat wypowiadał się w swych "P 1 e ś $n i$ a $c h \quad N i s i$ b $1 j s k i c h{ }^{2}$. Jak Eerem patrzy na kapłana, jakich przymiotów od niego wymagał 1 jakie obowiązki mu przypominal - oto problematyka, jaka się zajmiemy w niniejszym opracomaniu.

\section{W 1 e $1 \mathrm{k}$ a $\mathrm{g} \circ \mathrm{d} \mathrm{n}$ o ść k a p $z$ a $\mathrm{n}$ a. Efrem pod-} kreśla, że kapłaństwo jest darem Boźym, danym przez Chrystusa: "Duchowy to 1 święty, wzniosły 1 nieposzlakowany urząd, jaki nam niegodnym przyniósł Chrystus, gdy na ten świat przyszedł. /.../ Dzię-

1 Oratio de sacerdotio. Średniowieczni kopiści umieścili ją wóród pism św. Jana Chryzostoma jako VII księgę jego traktatu "O kapłaństwie". Już jednak Mauryni wydający dzieła Jana, Chryzostoma doszl1 do wniosku, ze ktoś inny jest jej autorem 1 umieścili ja wóród jego p1sm nieautentycznych /PG 48, 1067-1070/, rzymsk1 zaś wydawca dzieł św. Elrema - J.S. Assemani umieściz ją wich trzecim tomie/S. Ephraem, Opera omnia Graece, III, Romae 1774, 1-6/. Za dzieło Efrema uważają tę mowę tacy uczeni, jak: 0. Bardenhewer, P. Zingerle, D. Hemmerdinger, J. Czuj, A. Bober. Równiez M. Geerard umieszcza ją wśród zachowanych w języku greckim pism Efrema/Clavis Patrum Graecorum, II, Turnhout 1974, s. $410 \mathrm{nr} 3977$. PosługuJemy się jej polskim przekładem dokonanym w oparciu greck1 tekst Assemaniego przez ks. W. Kanie, wydanym oddzielnie/Sw. Efrem, Mowa o kapłaństwie, Tarnów 1983, Głos Trydycj1 9, s8. 12\%.

2 Carmina Nisibena, wyd. krytyczne E. Beck, Lovanii 1961 - CSCo 218219. Posługujemy się ich polskim przekładem w rękopisie opracowanym przez ks. W. Kanię. 
k1 niech będą Zbawicielowi, iz dał ziemi ten lśniący 1 oczyszczający dar 1 oświecił łaską kapłanów, ażeby jak światła rzucali światu promienie! ${ }^{3}$. Ponieważ kapłaństwo jest darem Bożym, dlatego ten tylko moze ublegać się o nie, kto jest powołany przez Boga: 'Dziwiesi bracia, na widok,jak niejeden śmie sięgać po kapłaństwo, choć nie jest powołany przez łaskę Chrystusa" ${ }^{4}$. Kto je sobie samowolnie przywłaszcza, śmierć 1 ogień sobie gotuje, "bo najczystszy Bóg nie ma upodobania w przystępujących zuchwale do święceń ${ }^{5}$."

Jak patrzy Efrem na kapłaństwo, widzimy w dalszych jego słowach: "Padam na kolana 1 ze łzami proszę, aby m1 wolno było mówić o kapłaństwie/.../. Nie przestanę, bracia,chwalić wzniosłej godności,jaką dała Trójca potomkom Adaman". Nazywa on kapłaństwo "cudem nadzwyczajnym, niewypowiedzianą mocą, budząca grozę tajemnica /... Kapłaństwo jest pełną blasku tarczą, niezachwianą wieżą, murem nie do zburzenia, budowlą mocną, wznoszącą się z xiem1 aź do nieba ${ }^{7}$. Godność kapłaństwa - przypomina EPrem - płynie ze stosunku kapłana do Eucharyst11. Nie moźna bowiem mówić o kapłaństwie w oderwaniu od ofiary Eucharystycznej: "Wino, pszenica 1 kapłaństwo łączą się ściśle z sobą. Wino i pszenica służą, hapłaústwo jest wolne. Te trzy rzeczy razem składają Królowi większą od wszelkich skarbó moc swych owocóm na miłą ofiarę. Wino daje krew, pszenica chleb, kapłaństwo zaś wzlatuje uenie do nieba, aby ujrzé́ Tego, który jest niewidzialny. Upadłszy przed tronem błaga Pana za sługi, ofiarując mu $1 \mathrm{ch} \nmid z y i$ westchnienta, prosząc dobrego Króla o miłosiordzie 1 łaskę, aby Duch Swięty zstąpił i uświęcił złożone na ziemi dary. /.../ Te dwie rzeczy - chleb $i$ wino - nie sprawiłyby na ziemi niczego, gdyby nie przyłączył się do nich głos niebieski 1 nie uświęcił darów" ${ }^{8}$.

Wielka godność kapłaństwa płynie też z jego stosunku do innych sakramentów. Lączy się ona szczególnie z władzą odpuszczania grzechów, co Efrem ujmuje następująco: "Bez czcigodnego kapłaŕstwa nie

3 Oratio de sacerdotio 4, PG 48, 1068, Mowa o kapłaństwie, dz.cyt., s. 5-7/cytuję: Mowa/.

4 Tamze, 9, $P G 48,1070$, Mowa, s. 11.

5 Tamże, 7 i $9, P G 48,1069-1070$, Mowa, s. 10.

6 Tamze, 1-2, PG 48, 1067, Mowa, s. 5.

7 Tanże, 1 .

8 Tamże, 3, PG 48, 1067-1068, Mowa, s. 7 . 
ma dla ludzi odpuszczenia grzechów". Tylko ta "święta godność zmywa z dusz naszych brudy /...l, z występnych czyni naczynia święte, z nieprzyzwoitych czyste 9" Kapłan - mówi dalej EPrem - uczestniczy w posłannictwie Chrystusa, który jest pośrednikiem między Bogiem 1 ludźm1. Uczestnicząc zaś posłannictwie Chrystusa, "nasze modły zanosi do nieba, za sługami wstawia sie do Pana /... z samym Panem Aniołów, ze Stwórcą 1 Dawcá świata swobodnie przestaje 1 wyprasza wszystko, czego tylko pragnie"10.

Sławny diakon nie tylko ukazuje wielką godność kapłańską, ale tez upomina, aby wierni należycie odnosill się do kapłanów, bo są ont sługami samego Boga: "Ze czcia odnośmy się do tych, którzy zostali zaszczyceni kapłaństwem./.../ Kochajmy kapłanów, bo oni są przyjaciółmi dobrego Boga 1 wstawiaja się za nami 1 za całym światem. Czcij kapłanów, wypełniając przez to przykazanie Chrystusa, które mćwi: 'Kto przyjmie proroka, w imię proroka, otrzyma zapłate proroka" / Mt 10, 41/. Choć nie wiesz o jakim kapłanie, czy jest godny urzędu, szanuj go dla przykazania Chrystusal Bo Jak nie traci wartości złoto, choćby się zanieczyściło w błocie, ani nie zmienia się najpiękniejsza perła wśród brudnych rzeczy, tak nie staje się brudnym kapłaństwo, choćby je otrzymał człowiek niegodnyn11.

2. $S$ i e t o ś ć $k$ a p 1 a $n$ a. Skoro kapłástwo jest tak wzniosłą godnością, wymaga ono świętości od kapłana. Swiętó́ć kapłańskiego życia ma się wyraźać sposób szczególny przez służbę Bogu 1 ludziom oraz przez ćwiczenie się w cnotach. Wielki nacisk kładzie Efrem na niewinność 1 czystość kapłana, który ma byé "wstrze= mięźliwy jak Józef i czysty jak Jozue"12. Tych zaś, którzy zostal1 powołan1 łaską Chrystusa do tak wielkiej godności, upomina: "Staraj się Temu, który cię powołał, służyé przez czystość, sprawiedliwość, mądrość i dziewictwon 13 .

9 Oratio de sacerdotio 312 , PG 48, 1067, Mowa, s. 6-7.

10 Tanże, 31 1, PG 48, 1067, Mowa, s. 5-6.

11 Tauże 6, PG 48, 1069, Mowa, s. 10 .

12 Tamże, 8, $P G 48,1070$, Mowa, s. 11.

13 Tamże. 
Kapłan "z ludzi wzlęty, dla ludzi ustanowiony"/Hbr 6, 1/ spotyka się z nimi codziennie. Niemozliwe jest oderwanie sie zupełne od wiernych, którzy powierzeni są jego pieczy. Stąd Efrem przypomina, Jakı winien być kapłan w stosunku do wiernych: "Bądź gorliwy jak Eliasz, pilny jak Jeremiasz./.../ gościnny jalk Abraham, miłosierny jak Dawid, łagodny jak Mojzesz"14.

Kapłan winien byé mężem modlitwy, bo "on modły zanosi do nieba, za sługami wstawia się do Pana". Jego obowiązkiem jest proszenie dobrego Króla o miłosierdzie i łaskę ${ }^{15}$. Ma on téz być osobą przykładną 1 miłą oraz odznaczać się łagodnością, bo tylko wtedy wierni będą go naśladować. Efrem występując niejako w imieniu całej wspólnoty, zwraca się do Abrahama biskupa Nisibis, a przez to do wszystkich biskupów 1 kapłanów, którzy są pasterzami ludu: "Ty będziesz się szanował, a my ciebie, bo gdy jest zrozumienie, lud 1 kapłan szanują się wajemnie ${ }^{16}$.

3. Z a d a r I a k a p 1 a n a. W mowie "O kapłaństwie" nie wylicza Efrem szczegółowo obowiązków, jakie wziął na siebie kapłan przez przyjęcie święceń. Czyni to natomiast przy okazji omawiania pasterskiej działalności biskupów w "Pieśniach Nisibijskich". Podkreśla wich, ze kapłaństwo jest "darem nieba", a nie ludzkim. Nie trzeba go więc uzaleźniać od władzy tego świata, aby diabeł go sobie nie podporządk ował traktując jako władzę ludzką 17 : Poprzez porównania poucza, ze kapłan jest jakby rolnłkiem, który ma siać słowa Boże w glebę, dla jej oczyszczenta z wszelkich błędów. Jest światłem 1 solą Kościoła przez czystość nauki 1 dobry przykład ${ }^{18}$. Jest lekarzem, który według potrzeb ma rozdzielać lekarstwa w celu leczenla 1 ochrony przed chorobami: "Zabierz z sobą - pisze - niezliczoną llość lekarstw 1 wstań, aby przebiec łąki"19. Jest tez mý́liwym 1 łowcą dusz.

Każdy duszpasterz rozpoczynając swą pracę musi dołożyé wszelkich

14 Oratio de sacerdotio 8, $\mathrm{PG} 48,1070$, Mowa, s. 11.

15 Tamże, 3, PG 48, 1067, Mowa, s. 7.

16 Carmina Nisibena 19, 12, CSCo 218, 52.

17 Carmina Nisibena $17,10, \operatorname{csco} 218,47$.

18 Carmina Nisibena $18,10, \operatorname{csco} 218,49$.

19 Tamże, 19, 11, CSco 218, 52. 
starań, aby poznać tych, którzy powierzeni sá jego pieczy: "Wypada, aby nowy pasterz zaoplekował się swym stadem, aby znał jego liczbę 1 potrzeby" 20 . Winien również dbać o zdrowie owiec 1 opiekować się chorymi, troszczyć się o wszystkie, żywić na łąkach Ksiąg świętych 1 poić prawowierną nauką. Wytrwałość ma być jego murem, krzyí podporą, prawdą 1 pokojem 21 . Jako odważny pasterz ma naśladować Dawida: "Jeśli ten wyrwał zabłąkaną owcę z paszczy lwa, to ileż ważnıejszym staje się wyrwanie diabłu odkupionej Krwią Chrystusa duszy" 22 .

Jednym z podstawowych obowiązków kaźdego pasterza jest teź udzielanie sakramentów św. "Daj choremu - mówi Efrem - lekarstwo, a éwiętemu ochronę" 23 . Lekarstwem dla chorego chrześcijanina jest Pokuta, a ochroną Eucharystia. Kapłan winien tak postępować, by być wzorem dla naśladowania przez wiernych. Dlatego teź nasz Swięty zwraca się do wiernych 1 nakazuje im, by zawsze starali się być podobnymi do swego pasterza: "Bądźcie podobni do waszego przywódcy, szukajcie pokoju w jego czystośd, łagodności w jego pogodzie 1 świętości nauki w jego wiedzy" 24 .

Efrem wreszcie bardzo mocno podkré́la, że powodzeniu pracy kapłanów sprzyja ubústwo Kościoła i jego kapłanów: "Niech Kościół nie posiada wielu bogactw, lecz niech sie zadowoli posiadaniem dusz i niech przez wyrzeczenie wzbudza pociziw" ${ }^{25}$. Bogactwo bowiem zagraza wolności każdego człowieka, a tym bardziej wolnośc1 kapłana. Zachęca więc, aby duszpasterz wyrzekł się bogactw, aby "unicestwił tę przewlekłą chorobę" 26 .

Uwagi nasze kończymy słowami papieża Jana XXIII, jakie wypowiedział podczas III sesji Synodu Rzymskiego: "Jest nam bardzo miło zachęclé nasz kler ukochany, aby z ochota zwracał się do tych przeczystych źródeł, jakie wydał Kościół pierwotny. One nam bowiem

20 Carmina Nisibena 20, 3, CSCo $218,54$.

21 Tamże, 19, 4, CSCO 218, 51.

22 Tamże, 19, 5, CSco 218, 51 .

23 Tamże, 19, 11, CSCo 218, 52.

24 Tamze, 15, 1-2, $\operatorname{CSC0} 218,40$.

25 Tamże, 21, 7, $\operatorname{CSCO} 218,56$.

26 Tamże, 18, 1, $\operatorname{csco} 218,50$. 
otwierają szerok1 widok na pole pasterskiej posług1, one tez podaja pełne mądrości pouczenia o owocnej jego uprawien" 27 .

$$
\text { Ks. Leszek Stręk - Jodłowa }
$$

DE EXIMIO SACERDOTIS MUNERE IUXTA MENTEM S. EPIRAEMI SYRI /Argumentum/

Hac in dissertatiuncula auctor copiosissimis S. Ephraemi Syri sententis ac locutionibus dignitatem, sanctitatem ac munera sacerdotis adimplenda exponit. 


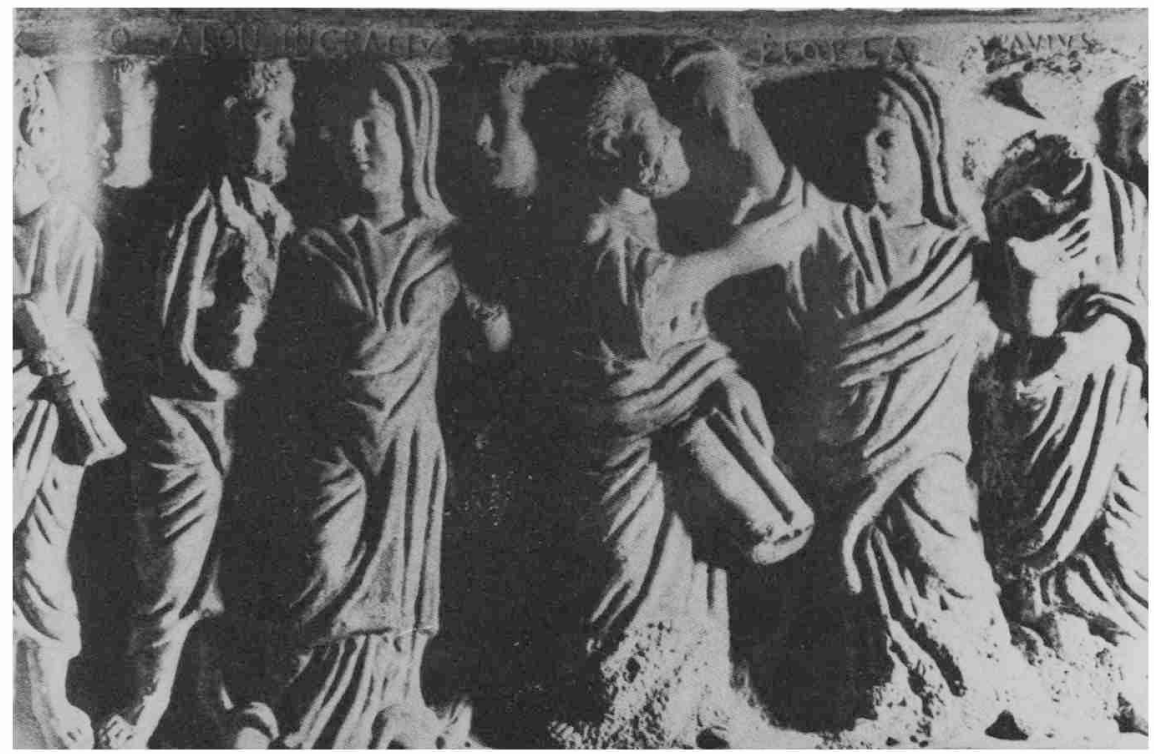

1. Środkowa scena sarkofagu, Saragossa, kościół 18 Męczenników, 1 poł. IV wieku.

$1 x^{2} 5 x^{-3}$

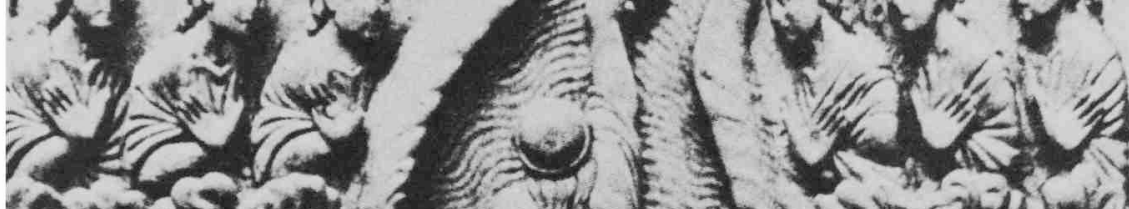

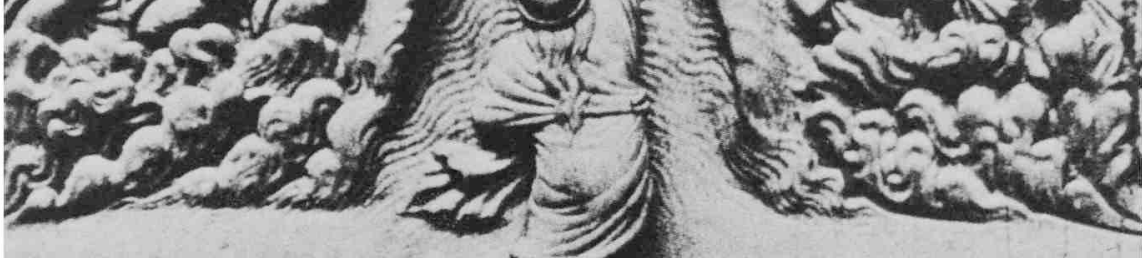

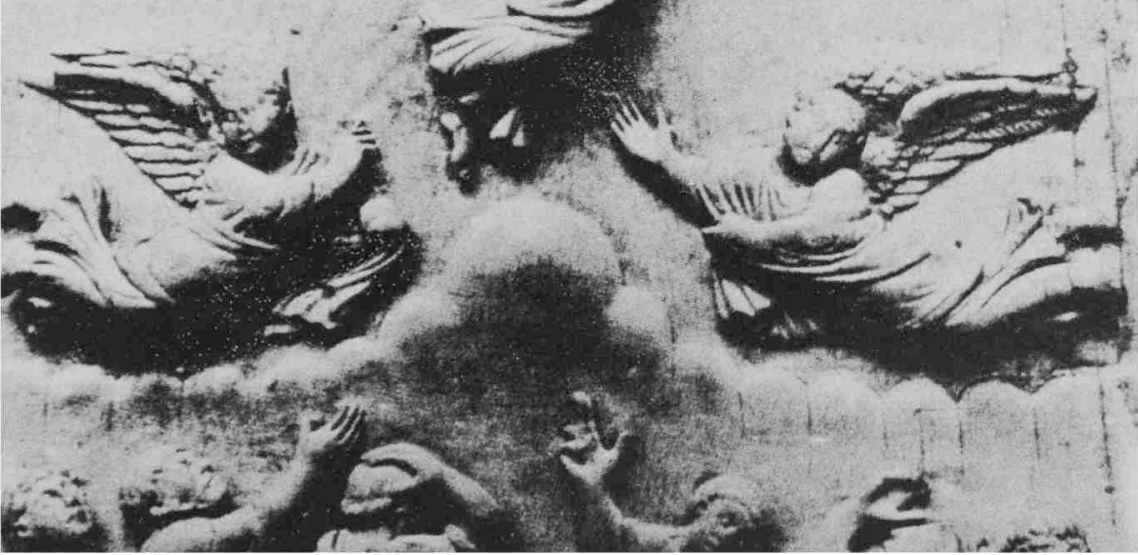

2. Wniebowstąpienie. Fragment karolińskiej oprawy książkowej, kość słoniowa IX-X wiek, Marburg 


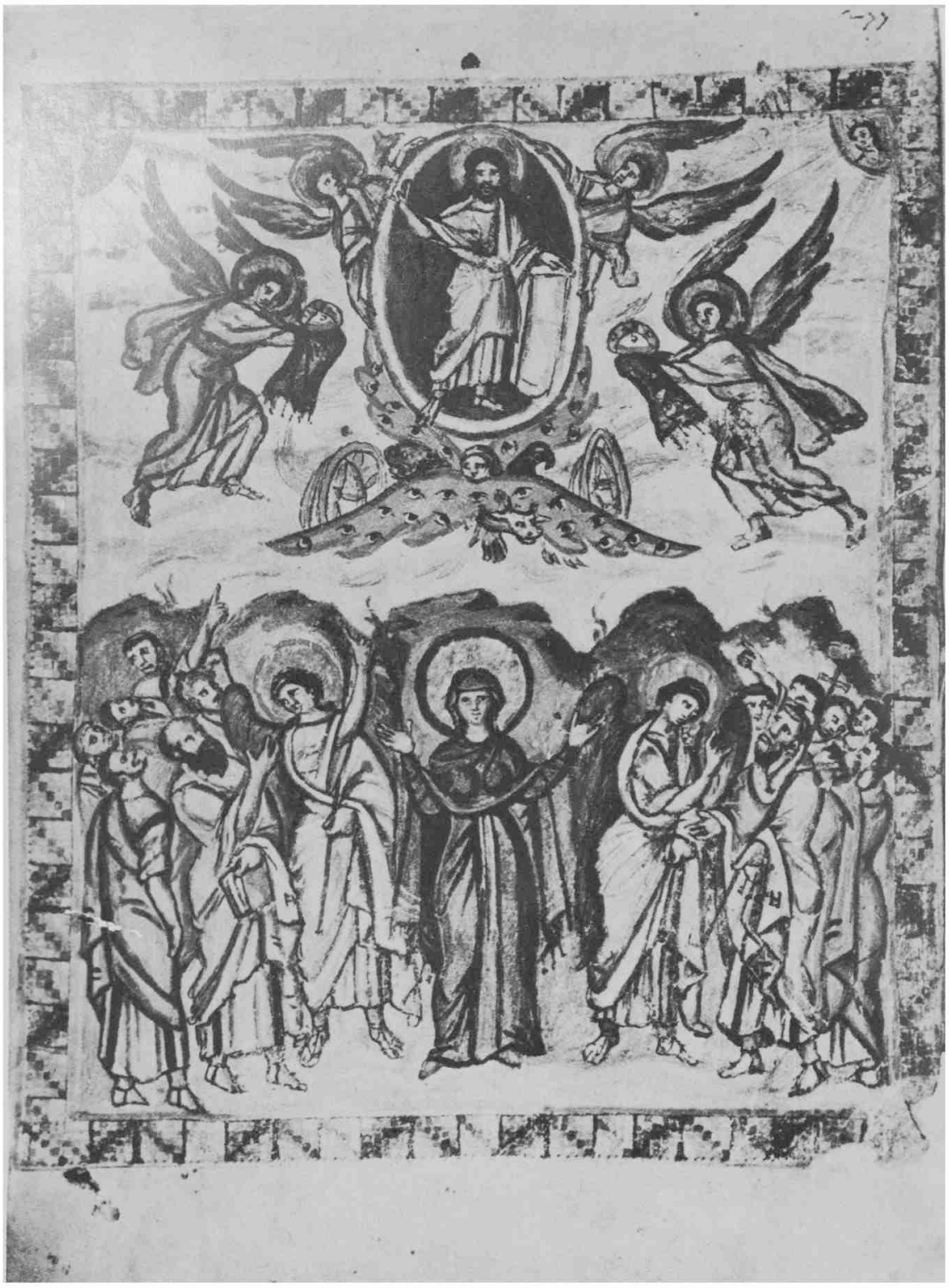

3. Kodeks Rabulasa, karta 13 v. 586 r., Florencja, Biblioteka św. Wawrzyńca. 